\title{
Retention of ciliates and flagellates by the oyster Crassostrea gigas in French Atlantic coastal ponds: protists as a trophic link between bacterioplankton and benthic suspension-feeders
}

\author{
Christine Dupuy ${ }^{1,2, *}$, Solange Le Gall ${ }^{1}$, Hans J. Hartmann ${ }^{2}$, Martine Bréret ${ }^{1}$ \\ ${ }^{1}$ CNRS/IFREMER, CREMA BP 5, F-17137 L'Houmeau, France \\ ${ }^{2}$ LBBM, Université de La Rochelle, Pôle Science Av. Marillac, F-17042 La Rochelle, France
}

\begin{abstract}
In French Atlantic coastal ponds of the Charente, oysters can grow under conditions where phytoplankton production is limited by nutrient exhaustion. Such ponds typically show a high concentration of ciliates and flagellates during the growing season $\left(1 \times 10^{4}\right.$ to $3 \times 10^{5}$ cells $^{-1}$ in June 1997). In order to evaluate the importance of the 'protozoan trophic link' for energy transfer from the 'microbial food web' to large benthic suspension feeders, we offered a coastal pond community of ciliates and flagellates as potential prey to the oyster Crassostrea gigas. Clearance rate, filtered particles and relative retention efficiency were evaluated. In the grazing experiment, $94 \%$ of ciliates and $86 \%$ of flagellates (size between 4 and $72 \mu \mathrm{m}$ ), were retained by the oyster. Whatever their size, protists were similarly retained by the oyster gills. In terms of carbon, oysters retain on average $126 \mu \mathrm{g} \mathrm{h} \mathrm{h}^{-1} \mathrm{~g}^{-1}$ dry weight, a value over 4 times higher than reported for phytoplankton. These results indicate that a field community of protists can contribute in coastal oyster rearing ponds to the energy requirements of the oyster C. gigas. We report here the first experimental evidence of a significant retention of a protist community by oysters, supporting the role of protists as a trophic link between picoplankton and benthic filter-feeding bivalves.
\end{abstract}

KEY WORDS: Bivalve - Oyster - Food source - Coastal pond - Micrabial food web - Protist - Picoplankton $\cdot$ Trophic link

\section{INTRODUCTION}

Oysters obtain energy resources by filtering particles from seawater, and their growth depends upon the nutritive value of the retained seston (Berg \& Newell 1986) and the trophic capacity of coastal waters (Héral 1987). The natural habitats of the oyster Crassostrea gigas are open coastal ecosystems, rocky shores or mud flats. Charente-Maritime, on the French Atlantic coast, is the most important European oyster farming area. Shellfish culture has developed in muddy bays (rearing areas of $4800 \mathrm{ha}$ ) and in semi-closed coastal ponds (3000 ha), characterized by relative confinement and low water-renewal rates.

·E-mail: cdupuy@ifremer.fr
The importance of phytoplankton in the nutrition of oysters is well documented (Héral 1987, Pastoureaud et al. 1996). However, in oyster rearing environments, such as the particularly light-limited turbid estuary of Marennes-Oléron, or in coastal ponds of the Charente where nutrients are quickly exhausted, phytoplankton cannot entirely account for the energy requirements of oysters (Héral 1987)

In the oceans, more than $50 \%$ of the primary production is due to unicellular organisms less than $3 \mu \mathrm{m}$ in size ( $\mathrm{Li}$ et al. 1983, Platt et al. 1983, Glover et aì. 1986), which constitutes a nutrient source of particulate and dissolved organic matter for heterotrophic organisms. Dissolved organic matter (DOM) present in coastal waters (Pomeroy \& Wiebe 1993) provides a potential for high bacterial production. Thus, in the 
Atlantic coastal ponds, bacterioplankton constitutes $50 \%$ of the planktonic carbon biomass (Frikha et al. 1987). Such heterotrophic bacterioplankters, with typically high growth rates and growth efficiencies, represent a significant energy pathway by recycling DOM into particles potentially available to upper trophic levels (Pomeroy 1974, Azam et al. 1983، Fenchel 1988).

However, small-sized bacteria and autotrophic picoplankton are not retained by gills of bivalves, particularly oysters (Shumway et al. 1985, Héral 1987, Riisgård 1988, Barillé et al. 1993). Flagellate and ciliate protists, which consume bacteria and phytoplankton, are abundant in coastal ecosystems (Revelante \& Gilmartin 1983, Sherr et al. 1986a, Fenchel 1988, Leakey et al. 1992) and are preyed upon by the numerous organisms of zooplankton, particularly copepods (Berk et al. 1977, Jonsson \& Tiselius 1990, Gifford \& Dagg 1991, Hartmann et al. 1993). Protozoa have been suggested as a major trophic link between picoplankton and micro or macroplankton (Porter et al. 1979, Conover 1982, Sherr et al. 1986b, Stoecker \& Capuzzo 1990).

Likewise, protists might represent a trophic link between bacteria and filter-feeding bivalves. Some data support this assumption. Tintinnids were observed in the stomachs of oysters (Paulmier 1972). Moreover, filter-feeding benthic molluscs retain protists, as exemplified by contaminations of bivalves by toxic flagellates (Sournia et al. 1991). In a mixed cell suspension of phytoplankton and dinoflagellates, 6 different species of bivalves were able to selectively clear and digest dinoflagellates (Shumway et al. 1985). Recently, Bardouil et al. (1996) showed that Crassostrea gigas easily consumes a nontoxic dinoflagellate and Kreeger \& Newell (1996) clearly demonstrated in mussels the ingestion and assimilation of bacterial carbon via heterotrophic flagellates. From experimental work, Le Gall et al. (1997) reported significant retention and ingestion of cultured bacterivorous ciliates, Uronema sp., by the oyster C. gigas. Heterotrophic protists, which are abundant in coastal ecosystems, may thus constitute an alternative or complementary food resource for benthic filter feeders, allowing the indirect recuperation of DOM and picoplanktonic production otherwise not accessible to them.

We present evidence of oyster grazing on protists: a ciliate and flagellate community from a coastal oyster rearing pond was offered to oysters in a laboratory experimental setup. Clearance rate, filtered particles and relative retention efficiency were determined by following the taxonomic composition and relative abundance of the protist community over time in the presence or absence of actively filtering oysters.

\section{MATERIALS AND METHODS}

Oyster collection and acclimation. Oysters were collected in June 1997 from our oyster pond research facility 'Marais du Plomb' (L'Houmeau, near La Rochelle, French Atlantic coast). Twenty adult Crassostrea gigas (1 yr old, shell length $5 \mathrm{~cm}$ and mean dry tissue weight $1.64 \pm 0.29 \mathrm{~g}$ ) were transported to the laboratory, freed of epibionts and acclimated overnight at the ambient field temperature of $18^{\circ} \mathrm{C}$, in GF/C (Whatman) filtered coastal pond water. Just before the experiment, 10 actively filtering oysters were selected and placed in $1 \mathrm{I}$ Pyrex rectangular trays containing $800 \mathrm{ml}$ of $\mathrm{GF} / \mathrm{C}$ (Whatman) filtered coastal pond water.

Protist community: sampling and enumeration. The field planktonic community provided as potential food to the experimental oysters came from the coastal pond. Natural unfiltered oyster pond water was collected, using a 2.51 'Van Doorn' sampling bottle (Wildco), and held in the laboratory at $18^{\circ} \mathrm{C}$ in an opaque carboy until use. Ciliates and flagellates were fixed, stained and enumerated according to methods modified from Haas (1982), Caron (1983) and Sherr et al. (1994). For ciliate examination, $20 \mathrm{ml}$ samples were stained live for $10 \mathrm{~min}$ by adding proflavin hemisulfate solution (Sigma, $0.033 \% \mathrm{w} / \mathrm{v}$, final concentration $0.00066 \%$ ): preliminary comparative experiments showed that live staining had no deleterious effects on the ciliate community. Ciliates were then preserved by adding glutaraldehyde (Sigma electron microscopy grade, $25 \% \mathrm{v} / \mathrm{v}$ in $0.2 \mu \mathrm{m}$ filtered seawater, final concentration $1 \%$ ). The cells were enumerated in Utermöhl settling chambers (Hydro-Bios combined plate chambers), using a reverse epifluorescence microscope (Leitz DMIRB, $100 \mathrm{~W}$ mercury lamp and blue light excitation). Ciliate taxa were enumerated and identified under combined epifluorescence and interference contrast illumination (magnification: $\times 400$ or $\times 630$ ). Sizes of all cells (length and width) were measured through a calibrated ocular micrometer. Mean cell volume of each ciliate taxon was calculated by equating the shape to standard geometric configurations. The cell volume was converted into carbon units, using a theoretical carbon/volume ratio of $0.17 \mathrm{pg} \mathrm{C}$ $\mu \mathrm{m}^{-3}$ (Putt \& Stoecker 1989), corrected for glutaraldehyde fixative according to Leakey et al. (1994).

For flagellate counting, $20 \mathrm{ml}$ samples were preserved with formaldehyde (paraformaldehyde powder Sigma, $8 \mathrm{w} / \mathrm{v}$ in $0.2 \mu \mathrm{m}$ filtered seawater, final concentration 1\%); each sample was concentrated to $10 \mathrm{ml}$ in a filtration tower mounted with a black 0.6 $\mu \mathrm{m}$ pore, polycarbonate membrane (Nuclepore) and a cellulosic backing filter (Whatman $1 \mu \mathrm{m}$ ) and stained by primulin (direct yellow 59 from Sigma; working 
solution was according to Sherr et al. [1994]: $250 \mu \mathrm{g}$ primulin in $100 \mathrm{ml}$ of $0.1 \mathrm{M}$ Trizma $\mathrm{HCl}$ at $\mathrm{pH} 4.0 ; 50$ $\mu \mathrm{g} \mathrm{ml} \mathrm{m}^{-1}$ final concentration). The primulin method allows observation of cell outlines and permits distinguishing autotrophic from heterotrophic flagellates by repeated interchange of the filter sets (Caron 1983): phototrophic cells (faint orange under UV $365 \mathrm{~nm}$ excitation and red colored under green 450 to $490 \mathrm{~nm}$ excitation) and heterotrophic cells (blue under UV excitation and invisible under green excitation) were separately enumerated. Fields were viewed first for primulin fluorescence to locate flagellates, and then for chlorophyll a fluorescence (by changing the filter set) to confirm which of these cells were pigmented. Length and width of 100 flagellates were measured (observation under UV $365 \mathrm{~nm}$ excitation and magnification $\times 630$ ) from triplicate samples. However, the presence of the black Nuclepore filter did not allow any observation of the flagellates under light microscopy and thus prevented identification of taxon or species.

Experimental protocol for the study of protist retention. The possible influence of oyster filtration upon the natural protist community was studied for $90 \mathrm{~min}$ in an experimental chamber at $18^{\circ} \mathrm{C}$ by comparing the evolution of protist abundances in triplicate suspensions with or without filtering oysters. At the start of the feeding period, 6 oysters were transferred to individual $500 \mathrm{ml}$ Pyrex rectangular trays containing $400 \mathrm{ml}$ natural unfiltered oyster pond water, gently homogenized with a magnetic rod to prevent sedimentation. As protists are fragile organisms, only a moderate homogenization was carried out in order to avoid cell damage; because of this restriction, the volume of the protist suspension was limited to $400 \mathrm{ml}$, to maintain a homogenous concentration of living protists.

Two experimental treatments were performed each in triplicate: the natural ciliate and flagellate suspensions were (1) allowed to evolve as controls, in the presence of 3 living but nonfiltering oysters, tightly tied up by a knotted string (controls for physical sedimentation of the suspension), or (2) delivered to 3 actively filtering oysters. It should be noted that, at the natural food concentration used in this study, there was no visible production of pseudofaeces. Dry tissue weight of each oyster was recorded at the end of the experiment, and clearance rates and filtered particles were expressed per gram of oyster dry tissue.

Calculation of clearance rate, filtered particles and relative retention efficiency. In order to control the normality of oyster filtration in our laboratory experiments, the clearance rate was estimated and compared to literature data. Defined as the theoretical water volume entirely cleared from particles (assuming 100\% retention) per unit time and per oyster dry tissue weight $\left(1 \mathrm{~h}^{-1} \mathrm{~g}^{-1}\right.$ ) (Bayne \& Widdows 1978), the clearance rate was calculated from the time course of the ciliate or flagellate cell concentration in the triplicate suspensions with filtering oysters. During the first 5 min of the experiment, individual variations in establishing a regular oyster filtration prevented a reliable study of the change in protist abundance in the triplicate suspensions: therefore, we selected the subsequent sampling time (15 $\mathrm{min})$ as the most appropriate 'standard' time in our clearance experiment. Assuming exponential decline of the retained cells, the clearance rate was calculated according to Coughlan (1969) during the first $15 \mathrm{~min}$ :

$$
F=\frac{\ln C_{0}-\ln C_{t}}{t-t_{0}} \times V
$$

where $F$ is clearance rate $\left(1 \mathrm{~h}^{-1}\right), V$ is volume of the suspension $(1), C_{0}$ is the initial concentration of the suspension (cells ${ }^{-1}$ ), $C_{t}$ is the concentration at time $t$ (cells $\mathrm{l}^{-1}$ ) and $\left(t-t_{0}\right)$ is the time interval (h). Taking into account that weight-specific filtration decreases with increasing body size, standardized clearance rates were calculated according to Riisgård (1988): $F / W^{\text {b }}$, where $F$ is clearance rate $\left(1 \mathrm{~h}^{-1}\right), W$ is dry tissue weight (g) and b equals 0.73 for Crassostrea virginica (Riisgård 1988).

The number of filtered particles, which is the number of cells of each protist taxon retained per unit time and per gram of oyster dry tissue (cells $\mathrm{h}^{-1} \mathrm{~g}^{-1}$ ), was calculated directly from the difference in the number of cells present between $t_{0}$ and $t_{15} \mathrm{~min}$.

To investigate the possibility of differential grazing by the oyster among the various protist taxa, we compared the relative retention efficiencies for each ciliate taxon and each ciliate and flagellate order. Defined as the number of a specific cell type retained during $15 \mathrm{~min}$, relative to the initial available number of the same cell type at the beginning of the experiment, each relative retention efficiency $\left(E_{\mathrm{r}}\right)$ was calculated as a percentage for the difference in abundances at $t_{0}$ and $t_{15}$ min over the abundance at $t_{0}$

$$
E_{\mathrm{r}}(\%)=100 \times\left[\left(C_{0}-C_{l}\right) / C_{0}\right]
$$

where $C_{0}$ is the initial particle concentration (cells $\mathrm{l}^{-1}$ ) at $t_{0}$ and $C_{t}$ is the particle concentration (cells $1^{-1}$ ) at 15 min.

Initial ciliate and flagellate abundances from the triplicate experiments with filtering or closed oysters were compared using a Student's t-test (data were previously tested for normality by the KolmogorovSmirnov test). The ciliate and flagellate abundances in triplicate controls during the 90 min experiment were followed by comparing the 5 time points sampled $(0,5,15,45$ and $90 \mathrm{~min})$ with a regression test. 


\section{RESULTS}

\section{Taxonomic composition and standing stocks of protists in the coastal oyster pond in June 1997}

In the summer period of the experiment, the ciliate community of the coastal pond was abundant $(23700 \pm$

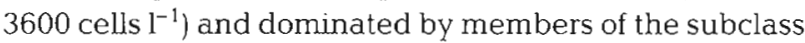
Choreotrichia, mainly represented by the order Choreotrichida, with Tintinnopsis spp. (10000 to

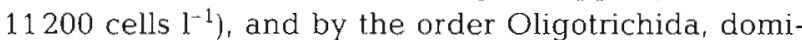

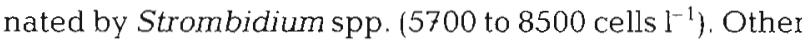
common taxa from the subclass Haptoria and order Haptorida (Mesodinium sp., Askenasia sp.) were also representative of the assemblage ( 3400 to 5700 cells l $^{-1}$ ). Ciliate sizes ranged from $8 \mu \mathrm{m}$ length for a Mesodinium sp. to $72 \mu \mathrm{m}$ for Strombidium conicum (Table 1). Prevalant ciliate cell lengths were between 16 and $48 \mu \mathrm{m}$.

Flagellate abundances in the coastal pond varied from 4.2 to $6.7 \times 10^{6}$ cells $\mathrm{l}^{-1}$ and flagellates accounted for about $99.5 \%$ of the protists enumerated in water samples. Mean flagellate sizes ranged from $4 \mu \mathrm{m}$ for heterotrophic to $6 \mu \mathrm{m}$ for autotrophic flagellates.

Tintinnina biovolumes as well as cell carbon were much higher than those of Oligotrichida and Hap- torida (for the most abundant taxon in each order, $19181 \mu^{3}$ for Tintinnopsis sp. [48 $\mu \mathrm{m}$ by $24 \mu \mathrm{m}$ ], $5579 \mu^{3}$ for Strombidium sp. [32 $\mu \mathrm{m}$ by $24 \mu \mathrm{m}$ ] and $2145 \mu^{3}$ for Mesodinium sp. [16 $\mu \mathrm{m}$ by $\left.16 \mu \mathrm{m}\right]$ ). By multiplying the taxon abundances at the beginning of the experiment by the carbon content per cell for each ciliate taxon, we estimated the quantity of ciliate carbon available to oysters: on average, $63.5 \mu \mathrm{g} \mathrm{Cl}^{-1}$. In this study, the flagellate carbon was not evaluated because flagellate taxonomy and biovolumes could not be determined.

\section{Grazing experiments}

The initial concentration in the natural suspension sampled for the grazing experiment was $23000 \pm$ 3900 ciliates $\mathrm{l}^{-1}$ and $4.5 \times 10^{6} \pm 1.12 \times 10^{6}$ flagellates $\mathrm{l}^{-1}$. Since all suspensions originated from the same coastal pond sample, initial protist abundances in the experimental trays showed no significant difference between controls and oyster treatments (Student's $t$-test, $n=6$, $p \gg 0.05)$. In the 3 control suspensions, ciliate and flagellate abundances remained relatively constant over $90 \mathrm{~min}$ (Fig. 1) according to regression test $\mathrm{r}^{2}=0.17$,

Table 1 Taxonomic composition, sizes, biovolumes and carbon content per cell of the protists community in the coastal pond in June 1997. Taxa printed in bold type were abundant and represented in all samples. Taxa identified by ${ }^{*}$ were rare and/or not present in all samples. When species were not identifiable, taxa were typified by their size

\begin{tabular}{|c|c|c|c|c|c|c|}
\hline $\begin{array}{l}\text { Order } \\
\quad \text { Suborder }\end{array}$ & Family & Species & $\begin{array}{c}\text { Species } \\
\text { length }(\mu \mathrm{m})\end{array}$ & $\begin{array}{l}\text { Width } \\
(\mu \mathrm{m})\end{array}$ & $\begin{array}{l}\text { Biovolme } \\
\quad\left(\mu \mathrm{m}^{3}\right)\end{array}$ & $\begin{array}{l}\text { Carbon per cell } \\
\left(\text { pg cell } l^{-1}\right)\end{array}$ \\
\hline \multirow{7}{*}{$\begin{array}{c}\text { Choreothrichida } \\
\text { Tintinninia }\end{array}$} & \multirow[t]{6}{*}{ Codonellidae } & Tintinnopsis sp. & 35 & 24 & 13994 & 2379 \\
\hline & & Tintinnopsis sp. & 40 & 24 & 15984 & 2717 \\
\hline & & Tintinnopsis sp. & 48 & 24 & 19181 & 3261 \\
\hline & & Tintinnopsis sp. & 48 & 40 & 53281 & 9058 \\
\hline & & Tintinnopsis sp. & 51 & 40 & 56632 & 9627 \\
\hline & & Tintinnopsis sp. & 56 & 24 & 22378 & 3804 \\
\hline & Codonellopsidae & Stenosemella sp. & 24 & 22 & 7603 & 1293 \\
\hline \multirow[t]{7}{*}{ Oligotrichnda } & Halteriidae & Halteria sp. & 27 & 19 & 3024 & 514 \\
\hline & \multirow[t]{6}{*}{ Strombidiidae } & Strombidium sp. & 24 & 19 & 2617 & 445 \\
\hline & & Strombidium sp. & 25 & 22.5 & 4307 & 732 \\
\hline & & Strombidium sp. & 32 & 24 & 5579 & 948 \\
\hline & & Strombidium sp. & 35 & 25.6 & 6863 & 1167 \\
\hline & & Strombidium sp. & 40 & 28.5 & 9569 & 1627 \\
\hline & & Strombidium conicum & 72 & 32 & 20642 & 3509 \\
\hline \multirow[t]{7}{*}{ Haptorida } & Didiniidae & Didinium sp. & 64 & 54 & 97716 & 16612 \\
\hline & \multirow[t]{6}{*}{ Mesodiniidae } & Unidentified & 16 & 16 & 2145 & 365 \\
\hline & & Unidentified & 27 & 14 & 2771 & 471 \\
\hline & & Mesodinium sp. & 8 & 8 & 268 & 45 \\
\hline & & Mesodinium sp. & 16 & 16 & 2145 & 365 \\
\hline & & Mesodinium pulex & 14 & 10 & 733 & 125 \\
\hline & & Askenasia sp. & 24 & 16 & 3217 & 547 \\
\hline \multirow{2}{*}{\multicolumn{3}{|c|}{$\begin{array}{l}\text { Autotrophic flagellate } \\
\text { Heterotrophic flagellate }\end{array}$}} & 6.2 & 4.2 & & \\
\hline & & & 4.1 & 3.5 & & \\
\hline
\end{tabular}



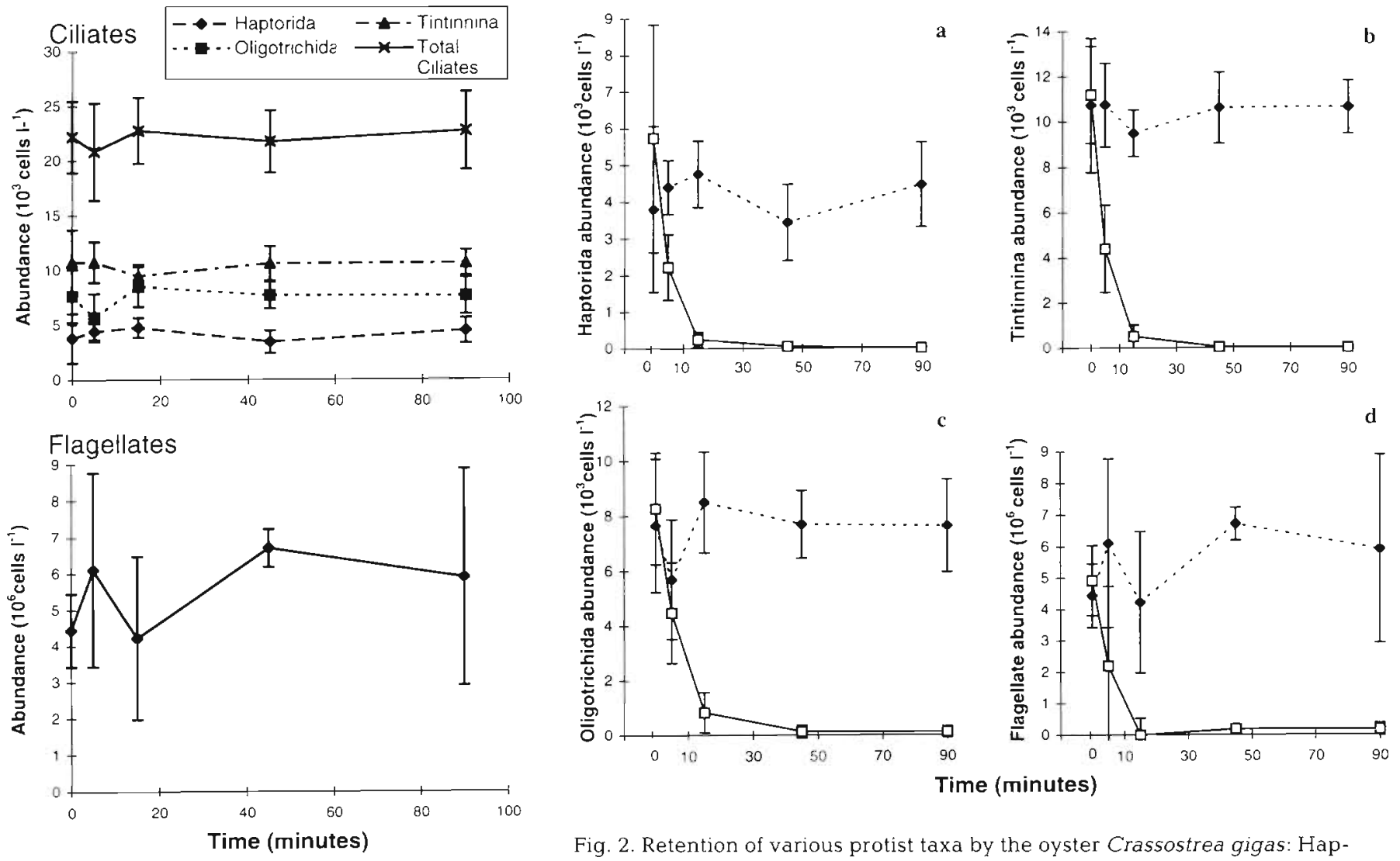

Fig. 2. Retention of various protist taxa by the oyster Crassostrea gigas: Haptorida (a), Tintinnina (b), Oligotrichida (c) and flagellates (d). Protist abundance data (mean $\pm \mathrm{SD}, \mathrm{n}=3$ ) were collected from 6 separate experiments performed in $400 \mathrm{ml}$ marine pond water suspensions with a closed, nonfilterabundances in control suspensions. Abundance data (mean $\pm \mathrm{SD}, \mathrm{n}=3$ ) were collected from 3 separate experiments, performed with a closed, nonfiltering oyster in a $400 \mathrm{ml}$ suspension of ing oyster $(\cdots)$ or with a filtering oyster $(\square-\square)$ coastal pond water

\section{Clearance rates, filtered particles}

$p \gg 0.05$ for ciliates and $r^{2}=0.23, p \gg 0.05$ for flagellates).

In the 3 experimental trays with filtering oysters, ciliates whose size was between 20 and $40 \mu \mathrm{m}$ were $100 \%$ retained; the relative retention efficiency in the experimental suspension within 15 min was $96 \%$ for Haptorida and Tintinnina (Fig. 2a, b) and 91\% for Oligotrichida (Fig. 2c). Similarly, flagellates decreased by $86 \%$ within $15 \mathrm{~min}$ in the trays with the filtering oyster (Fig. 2d). At the end of the experiment (90 min), virtually all ciliates and $96 \%$ of the flagellates had been retained by the bivalves.

The relative retention efficiency for each protist taxon, related to the protist sizes present in the suspension, remained constant in the size range dealt with in the study (Fig. 3), except for a slight decrease for the smaller and larger taxa: only $84 \%$ of the $4 \mu \mathrm{m}$ particles and $88 \%$ of the $72 \mu \mathrm{m}$ particles were retained. For concentrations below the pseudofaeces threshold, all protist from 4 to $72 \mu \mathrm{m}$ were similarly retained by the oyster gills.
Clearance rates of oysters averaged $4.0 \pm 1.31 \mathrm{~h}^{-1} \mathrm{~g}^{-1}$ for flagellates and $7.2 \pm 3.5 \mathrm{l} \mathrm{h}^{-1} \mathrm{~g}^{-1}$ for Oligotrichida ciliates (Table 2). The number of filtered particles, calculated between 0 and 15 min (Table 3), was dependent on protist taxon. Tintinnina were more readily retained (ca $27500 \pm 11500$ cells $\mathrm{h}^{-1} \mathrm{~g}^{-1}$ ) than Haptorida $\left(8900 \pm 4400\right.$ cells $\left.\mathrm{h}^{-1} \mathrm{~g}^{-1}\right)$ or Oligotrichida $(19600 \pm$

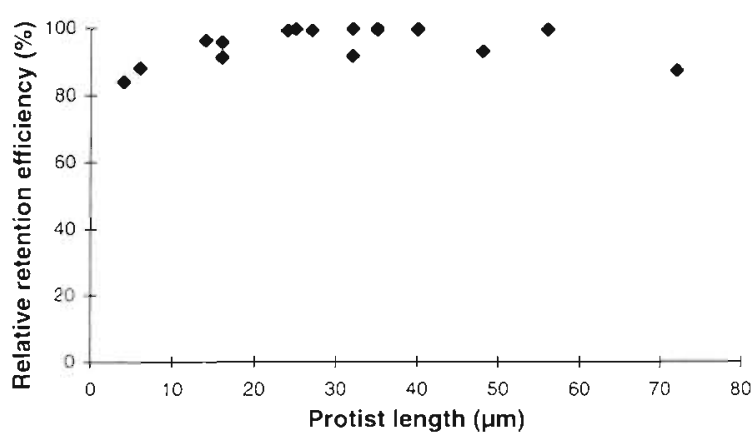

Fig. 3. Relative retention efficiencies of protists related to their size class 
Table 2. Cell abundances in experimental suspensions (cells $\mathrm{l}^{-1}$ at $t_{0}$ ) and standardized clearance rates by Crassostrea gigas ( $\mathrm{h}^{-1}$ $\mathrm{g}^{-1}$ ) for the different ciliate and flagellate taxa (mean $\pm S D, n=3$ ). When species were unidentifiable, taxa were typified by their size (length and width in $\mu \mathrm{m}$ )

\begin{tabular}{|c|c|c|c|c|}
\hline \multirow[t]{2}{*}{ Taxon (length/width in $\mu \mathrm{m}$ ) } & \multicolumn{2}{|c|}{$\begin{array}{l}\text { Cell abundances }\left(1^{-1}\right) \text { at } t_{0} \text { in experimental } \\
\text { suspension with an actively filtering oyster }\end{array}$} & \multicolumn{2}{|c|}{ Standardized clearance rate $\left(1 \mathrm{~h}^{-1} \mathrm{~g}^{-1}\right)$} \\
\hline & Mean & $\mathrm{SD}$ & Mean & $\mathrm{SD}$ \\
\hline \multicolumn{5}{|l|}{ Haptorida } \\
\hline Mesodiniuim sp. $(16 / 16)$ & 1178 & 237 & 3.6 & 0.7 \\
\hline Mesodiniidae $(16 / 16)$ & 1748 & 776 & 7.9 & 4.3 \\
\hline Mesodiniuim pulex $(14 / 10)$ & 2736 & 3178 & 4.1 & 4.5 \\
\hline Askenasia sp. $(24 / 16)$ & 76 & 132 & 2.5 & 4.4 \\
\hline Haptorida average & 5738 & 4192 & 5.5 & 2.3 \\
\hline \multicolumn{5}{|l|}{ Oligotrichida } \\
\hline Strombidinum sp. $(25 / 22.5)$ & 1026 & 1777 & 3.7 & 6.5 \\
\hline Strombidinum sp. $(32 / 24)$ & 3648 & 3288 & 4.9 & 6.4 \\
\hline Strombidinum sp. $(35 / 25.6)$ & 2318 & 4015 & 4.1 & 7.1 \\
\hline Strombidinum sp. $(40 / 28.5)$ & 114 & 197 & 2.7 & 4.7 \\
\hline Strombidinum conicum $(72 / 32)$ & 1064 & 628 & 4.9 & 3.5 \\
\hline Halteria sp. (27/19) & 76 & 132 & 0.0 & 0.0 \\
\hline Oligotrichida average & 8284 & 2028 & 7.2 & 3.5 \\
\hline \multicolumn{5}{|l|}{ Tintinnina } \\
\hline Tintinnopsis sp. $(35 / 24)$ & 152 & 174 & 4.9 & 4.3 \\
\hline Tintinnopsis sp. $(40 / 24)$ & 1102 & 1425 & 8.7 & 2.2 \\
\hline Tintinnopsis sp. $(48 / 24)$ & 9082 & 3933 & 6.5 & 5.8 \\
\hline Tintinnopsis sp. $(48 / 40)$ & 760 & 1316 & 3.6 & 6.2 \\
\hline Tintinnopsis sp. $(56 / 24)$ & 114 & 114 & 4.7 & 4.1 \\
\hline Tintinnina average & 11210 & 2146 & 7.8 & 1.5 \\
\hline \multicolumn{5}{|l|}{ Flagellates } \\
\hline Autotrophic flagellate & $1.38 \times 10^{6}$ & $1.07 \times 10^{6}$ & 4.9 & 3.0 \\
\hline Heterotrophic flagellate & $3.55 \times 10^{6}$ & $5.00 \times 10^{4}$ & 3.1 & 1.8 \\
\hline Flagellate average & $4.93 \times 10^{6}$ & $2.47 \times 10^{6}$ & 4.0 & 1.3 \\
\hline
\end{tabular}

10200 cells $\left.\mathrm{h}^{-1} \mathrm{~g}^{-1}\right)$. By multiplying filtered particles (cells $\mathrm{h}^{-1} \mathrm{~g}^{-1}$ ) by the carbon content per cell for each taxon, we obtained the quantity of ciliate carbon retained per hour per gram oyster dry weight ( $\mu \mathrm{g} \mathrm{C} \mathrm{h} \mathrm{h}^{-1}$ $\mathrm{g}^{-1}$ ), which averaged $126 \mu \mathrm{g} \mathrm{C} \mathrm{h} \mathrm{g}^{-1}$ (Table 3).

\section{DISCUSSION}

Marine planktonic protists (ciliates and flagellates) have recently been shown to be abundant in Atlantic coastal ponds: our estimations of protist abundances in our coastal pond at the time of the grazing experiment were respectively $23700 \pm 3600$ ciliates $\mathrm{l}^{-1}$ and $4.5 \times 10^{6} \pm 1.12 \times 10^{6}$ flagellates $\mathrm{I}^{-1}$. These protist abundances fell within the range estimated for the same pond by $\mathrm{O}$. Robin (pers. comm.), 10000 to 30000 cells $\mathrm{l}^{-1}$ for ciliates and $53 \times 10^{4}$ to $2.2 \times 10^{6}$ flagellates $\mathrm{l}^{-1}$.

In the absence of published data on ciliate abundances in the Atlantic coastal ecosystem near the coastal pond, we compared our data to results from distant estuaries and bays. In other temperate estuaries, ciliate abundances were in the same range, from

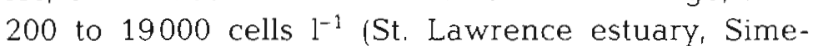

Ngando et al. 1995) and from 220 to 56000 cells $I^{-1}$ (northern Adriatic, River Po estuary, Revelante \& Gilmartin 1983). However, in the Gulf of Maine, ciliate abundances were higher: 350000 to 6000000 cells $1^{-1}$ (Montagnes et al. 1988).

In our study, the ciliate community was dominated by the order Choreotrichida with Tintinnopsis spp. (10000

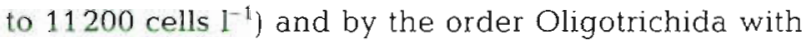
Strombidium spp. (5700 to 8500 cells $\mathrm{l}^{-1}$ ). O. Robin (pers. comm.) observed up to 300000 Tintinnina $1^{-1}$ in June 1996 in the same coastal pond of L'Houmeau. Tintinnina are also abundant in the Mediterranean Sea: 10000 ciliates $\mathrm{I}^{-1}$ in Villefranche-sur-mer (Rassoulzadegan \& Gostan 1976) and 8000 cells $1^{-1}$ in the southeastern Mediterranean (Alger Bay, Vitiello 1964). On the other hand, in a northern Mediterranean coastal lagoon (Etang de Thau), Tintinnina abundance was only 75 cells $1^{-1}$ (Lam-hoai et al. 1997), a value much lower than ours. Oligotrichida abundances (5700 to 8500 cells l $^{-1}$ ) were in the range of values collected by O. Robin (pers. comm.) during the spring of 1996 (4300 to 11500 cells $]^{-1}$ ) but lower than abundances (90000 cells $1^{-1}$ ) during the summer in Mediterranean Sea (Rassoulzadegan 1977). 
Table 3. Retention of various ciliate taxa by Crassostrea gigas expressed as filtered particles per unit time and unit oyster dry

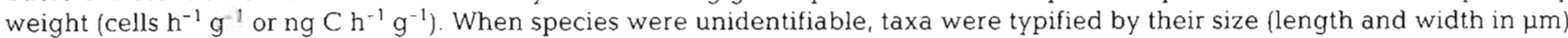

\begin{tabular}{|c|c|c|c|c|c|}
\hline \multirow{2}{*}{ Taxon (length/width in $\mu \mathrm{m}$ ) } & \multicolumn{2}{|c|}{ Filtered particles (cells $\mathrm{h}^{-1} \mathrm{~g}^{-1}$ ) } & \multirow{2}{*}{$\begin{array}{l}\text { Carbon per cell } \\
\quad\left(\text { pg cell }{ }^{-1}\right)\end{array}$} & \multicolumn{2}{|c|}{ Filtered particles (ng $\mathrm{h}^{-1} \mathrm{~g}^{-1}$. } \\
\hline & Mean & $\mathrm{SD}$ & & Mean & \\
\hline \multicolumn{6}{|l|}{ Haptorida } \\
\hline Mesodiniuim sp. $(16 / 16)$ & 2707 & 823 & 365 & 988 & 301 \\
\hline Mesodiniidae $(16 / 16)$ & 4441 & 2933 & 365 & 1621 & 1070 \\
\hline Mesodiniuim pulex $(14 / 10)$ & 1488 & 1394 & 125 & 186 & 174 \\
\hline Askenasia sp. $(24 / 16)$ & 227 & 393 & 547 & 124 & 215 \\
\hline Haptorida sum & 8863 & 4390 & & 2919 & 1583 \\
\hline \multicolumn{6}{|l|}{ Oligotrichida } \\
\hline Strombidinum sp. (25/22.5) & 3063 & 5305 & 732 & 2242 & 3883 \\
\hline Strombidinum sp. $(32 / 24)$ & 7811 & 7739 & 948 & 7405 & 7337 \\
\hline Strombidinum sp. $(35 / 25.6)$ & 6919 & 11985 & 1167 & 8075 & 13986 \\
\hline Strombidinum sp. $(40 / 28.5)$ & 276 & 479 & 1627 & 450 & 779 \\
\hline Strombidinum conicum $(72 / 32)$ & 2154 & 1126 & 3509 & 7560 & 3953 \\
\hline Halteria sp. $(27 / 19)$ & 158 & 274 & 514 & 81 & 141 \\
\hline Oligotrichida sum & 19643 & 10285 & & 25812 & 8643 \\
\hline \multicolumn{6}{|l|}{ Tintinnina } \\
\hline Tintinnopsis sp. $(35 / 24)$ & 432 & 528 & 2379 & 1029 & 1256 \\
\hline Tintinnopsis sp. $(40 / 24)$ & 2382 & 2899 & 2717 & 6472 & 7876 \\
\hline Tintinnopsis sp. $(48 / 24)$ & 22770 & 14798 & 3261 & 74254 & 48257 \\
\hline Tintinnopsis sp. $(48 / 40)$ & 1583 & 2742 & 9058 & 14342 & 24841 \\
\hline Tintinnopsis sp. $(56 / 24)$ & 318 & 342 & 3804 & 1210 & 1303 \\
\hline Tintinnina sum & 27487 & 11584 & & 97307 & 32081 \\
\hline Mean sum for all ciliates & 55993 & & & 126038 & \\
\hline
\end{tabular}

Our values for flagellate abundances were close to those obtained in the St. Lawrence estuary, $1.9 \times 10^{6}$ to $6 \times 10^{6}$ cells l $^{-1}$ (Lovejoy et al. 1993), and in the marine shallow-water Limfjorden in Denmark, $2 \times 10^{6}$ cells $l^{-1}$ (Andersen \& Sørensen 1986).

The wide range of these data shows the natural variability of protist abundances in the field. Moreover, since the coastal ponds are periodically closed systems in which the plankton community undergoes rapid fluctuations, it remains difficult to establish valid criteria for comparisons with open coastal systems. Nevertheless, in terms of potential carbon resources available to the oysters, the amounts calculated for ciliates (63.5 $\left.\mu \mathrm{g} \mathrm{C}^{-1}\right)$ were at the high level found for protozoa in coastal waters (St. Lawrence Estuary: 0.23 to $51.6 \mu \mathrm{g}$ $\mathrm{C}^{-1}$, Sime-Ngando et al, 1995).

When a coastal pond planktonic community was provided as potential food, clearance rates of oysters for protists $\left(4.0 \pm 1.3 \mathrm{l} \mathrm{h}^{-1} \mathrm{~g}^{-1}\right.$ for flagellates and $7.2 \pm$ $3.5 \mathrm{l} \mathrm{h}^{-1} \mathrm{~g}^{-1}$ for Oligotrichida ciliates) were in a range similar to values measured for phytoplankton by Gerdes (1983): $4.81 \mathrm{~h}^{-1} \mathrm{~g}^{-1}$, Deslous-Paoli et al. (1987): $4.7 \mathrm{l} \mathrm{h}^{-1} \mathrm{~g}^{-1}$, Riisgård (1988): $6.8 \mathrm{l} \mathrm{h}^{-1} \mathrm{~g}^{-1}$ and Soletchnik et al. (1991): 3 to $4 \mathrm{l} \mathrm{h}^{-1} \mathrm{~g}^{-1}$. However, in our experimental closed system, the concentration of particles rapidly declines during the experiment (Fig. 2); the standard time for our clearance experiment (15 $\mathrm{min}$ ), selected to avoid drawbacks related to the irregular establishment of oyster filtration during the first $5 \mathrm{~min}$, is too long to allow an accurate evaluation of clearance rates. Nevertheless, the possible negative effects of our suboptimal laboratory conditions on bivalve filtering efficiency (Jørgensen 1996) would only have resulted in the underestimation of our experimental values; field clearance rates of oysters for protists might be even higher.

The relative retention efficiency was $94 \%$ for the ciliates and $86 \%$ for the flagellates within $15 \mathrm{~min}$ from $400 \mathrm{ml}$ suspensions. This finding supports the results of Le Gall et al. (1997), who demonstrated that the oyster Crassostrea gigas retained Uronema sp., a cultured ciliate isolated from the oyster pond, with a $85 \%$ relative retention efficiency when present at a concentration close to field ciliate abundances. It also corroborates the observations by Paulmier (1972), who reported tintinnids to be abundant in the stomachs of wild oysters from the Atlantic coast. Likewise, Kreeger \& Newell (1996) estimated that $58 \%$ and $44 \%$ respectively of cultured heterotrophic nanoflagellates were retained by Geukensia demissa and Mytilus edulis, compared to values of $66 \%$ and $77 \%$, respectively, for the autotroph Isochrysis galbana. Ciliates and flagellates thus represent a potentially valuable food source and might be a significant component in the natural diet of suspension-feeding bivalves, provided their relative abundance is sufficiently high in the available seston.

To investigate the possible influence of particle size on oyster retention, we followed the abundance for 


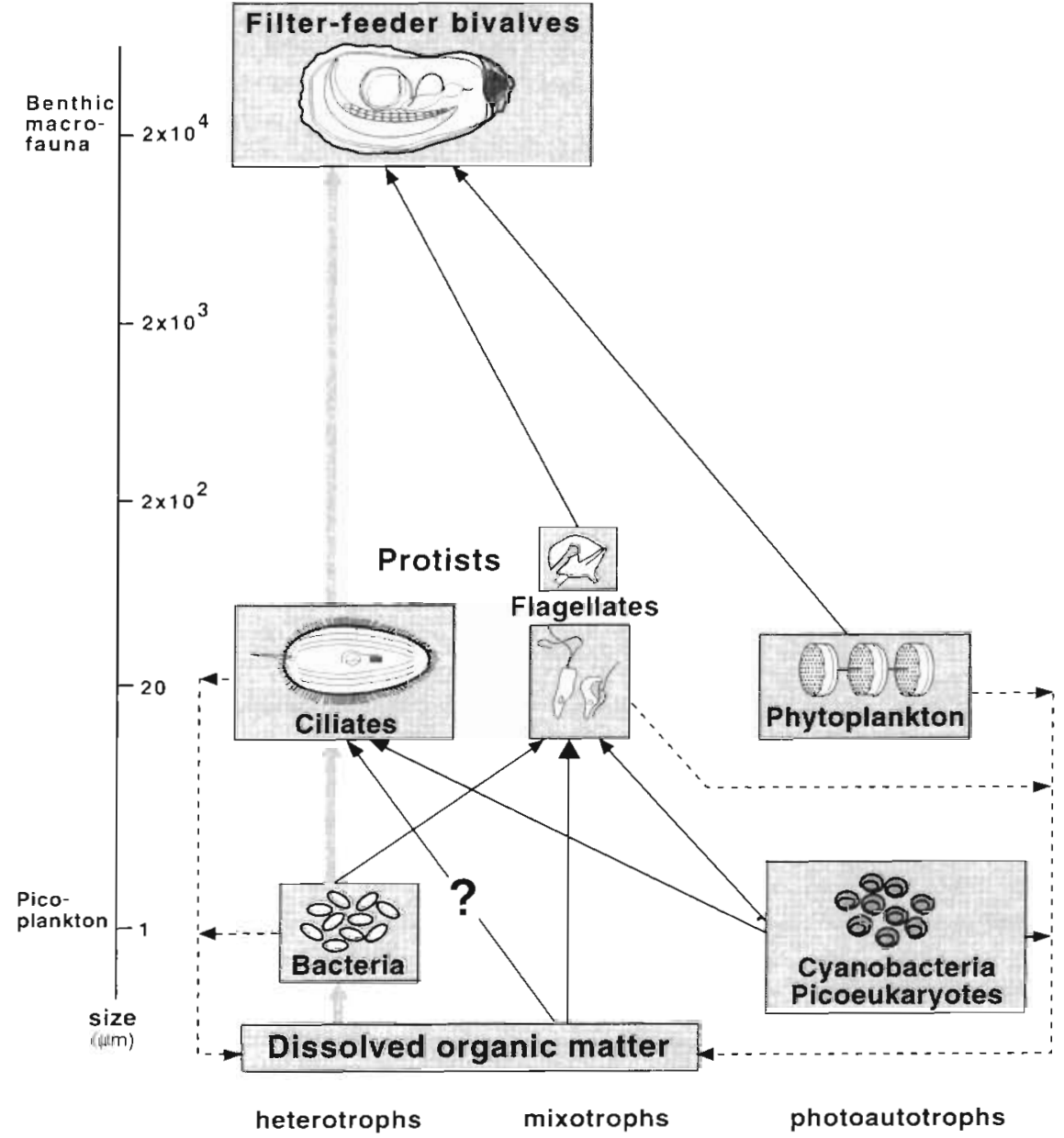

Fig. 4. Hypothetical microbial food web in an oyster growing area (modified from Le Gall et al. 1997)

each separate protist taxon in the experimental suspensions. In our experiments, ciliates and flagellates in a size range from 4 to $72 \mu \mathrm{m}$ were retained by the oyster, but the smallest heterotrophic flagellates $(4 \mu \mathrm{m})$ and the largest ciliates (Strombidium conicum, $72 \mu \mathrm{m}$ by $32 \mu \mathrm{m}$ ) displayed a slightly lower relative retention efficiency than the ciliates with sizes between 20 and $40 \mu \mathrm{m}$. Indeed, the flagellate sizes in our suspensions were at the lower end of the particle size spectrum known to be retained by Crassotrea gigas. Barillé et al. (1993) showed that this oyster has a limited capacity to retain small particles: $4 \mu \mathrm{m}$ particles (equivalent spherical diameter, ESD) were retained with $100 \%$ retention efficiency when sestonic load was low, but the limit increased to $12 \mu \mathrm{m}$ for higher sestonic loads; for particles below these thresholds, retention efficiency quickly decreased. Similarly Deslous-Paoli et al. (1987) demonstrated that the oyster is not able to retain small particles. Bougrier et al. (1997) reported that the selection of algae by the oyster C. gigas was independent of the size, volume or carbon content of each species (size between 3.65 and $9 \mu \mathrm{m}$ ESD). They observed, nevertheless, that some algae were preferentially filtered or rejected, due to cell shape and flexibility.

Conversely, mussels are able to retain even picoplankton-size particles (Kemp et al. 1990, Kreeger \& Newell 1996): in particular, in highquality food suspensions (expressed as the percentage of particles with chlorophyll fluorescence) prey retention and selection in Mytilus edulis is not dependent on the prey size (Newell et al. 1989). Reduction in food quality induced a drop in the ability to select living cells from silt particles, independent of size. As for oysters, however, these investigations demonstrated a selectivity based on cell shape (Newell et al. 1989). In contrast to the mussel, Crassostrea gigas cannot retain picoplankton-size particles at natural concentrations; therefore, the picoplankton-protozoa trophic pathway (Le Gall et al. 1997) may represent a significant energy source for the oyster (Fig. 4).

Ciliates are more nutritious prey than phytoplankton cells. They are relatively rich in nitrogen (C:N ratio near 4, Putt \& Stoecker 1989, Ohman $\&$ Snyder 1991; as compared to $>5$ for phytoplankton, Heinbokel et al. 1978, Burkhardt \& Riebesell 1997), and contain more carbon per cell than phytoplankton: our estimations of cell carbon contents, which are comparable to values previously reported in the literature $\left(3100 \mathrm{pg} \mathrm{C} \mathrm{cell}^{-1}\right.$ for Strombidium sp. [43 $\mu \mathrm{m}$ by $42 \mu \mathrm{m}]$, Stoecker \& Egloff 1987; $1100 \mathrm{pg} \mathrm{C} \mathrm{cell}{ }^{-1}$ for Strombidium sp. [43 $\mu \mathrm{m}$ by $30 \mu \mathrm{ml}$, Jonsson \& Tiselius 1990) were much higher than phytoplankton carbon content per cell from 10 to $21 \mathrm{pg} \mathrm{C}$ cell $^{-1}$ for Skeletonema costatum (Strathmann 1967, Burkhardt \& Riebesell 1997, Bougrier et al. 1997). $1.61 \mathrm{pg} \mathrm{C}$ cell $^{-1}$ for Phaedactylum tricornatum (FialaMedioni et al. 1983) and 10.3 pg C cell ${ }^{-1}$ for Navicula filata (Bougrier et al. 1997). In our experiment, on average, oysters retained $126 \mu \mathrm{g}$ ciliate $\mathrm{C} \mathrm{h}^{-1} \mathrm{~g}^{-1}$ for a ciliate concentration of $25000 \pm 3900$ cells $1^{-1}$. FialaMedioni et al. (1983) estimated that oyster filtering Phaedactylum tricornatum retained $27.5 \mu \mathrm{g} \mathrm{C} \mathrm{h}^{-1} \mathrm{~g}^{-1}$ for a phytoplankton concentration of $1 \times 10^{6}$ cells $\mathrm{l}^{-1}$. Ciliates may thus contribute to the carbon requirements of Crassostrea gigas in the same way as do het- 
erotrophic flagellates for the mussels Geukensia demissa and Mytilus edulis (Kreeger \& Newell 1996).

Most studies that have examined the nutritional importance of protists as a 'trophic link' have focused on pelagic consumers, such as zooplankton (Berk et al. 1977. Porter et al. 1979, Sherr et al. 1986b, Jonsson \& Tiselius 1990, Gifford \& Dagg 1991, Hartmann et al. 1993). However, only few studies have done the same for benthic consumers (Kreeger \& Newell 1996, Le Gall et al. 1997). Trophic coupling between pelagic protists and benthic suspension-feeders is poorly documented in aquatic food models (e.g. see Legendre \& Le Fèvre 1995).

In open water oyster beds, primary producers, in particular phytoplankton and resuspended microphytobenthos, can be considered important food sources for bivalve suspension feeders (Blanchard et al. 1997). In coastal ponds, on the other hand, even though microphytobenthic biomass may attain up to 25 times the higher levels of water column phytoplankton (Zanette 1980, Robert 1983), it is unlikely that the microphytobenthos is an important direct resource because its resuspension is low, due to a lack of turbulence. However, the DOM released by these autotrophs contributes to the important bacterial biomass that develops in coastal ponds: bacterioplankton constitutes $50 \%$ of the planktonic $\mathrm{C}$ biomass in oyster ponds of the Charente (Frikha et al. 1987). The bacteria, in turn, are a primary food source of heterotrophic/mixotrophic ciliates and flagellates which develop biomasses comparable to phytoplankton: in our coastal pond, the protist biomass was similar to the phytoplankton biomass of coastal oyster ponds from Bourgneuf Bay (Robert 1983). Since bacterivorous ciliates have a gross growth efficiency of about 40 (Johnson et al. 1982, Ohman \& Snyder 1991), relatively large amounts of bacterial $\mathrm{C}$ must be recovered by oysters via the protist trophic link.

In coastal pond habitats, bivalve molluscs are abundant and may be the dominant consumers of seston. Oysters are most likely opportunist omnivores, balancing their $\mathrm{C}$ (and $\mathrm{N}$ ) requirements by utilizing a wide variety of living and dead material (Riera \& Richard 1996), including protists. In addition to phytoplankton which cannot entirely account for the energy requirements of Crassostrea gigas (Héral 1987), oysters may derive nutrients from microzooplankton, in particular from protists. Our experiment presents the first data on oyster nutrition through grazing on a field community of protists. These results clearly show that suspension-feeding bivalves feed on ciliates and flagellates. Such a trophic relationship could be of primary importance for the transfer of $\mathrm{C}$, and probably $\mathrm{N}$, from the microbial food web to higher trophic levels in the benthos.
Acknowledgements. This work was supported by the CNRS (INSU-SDV), the IFREMER (DRV-RA), the LBBM (La Rochelle University) and by a doctoral grant from the 'Conseil Général de Charente-Maritime' (Région Poitou-Charentes). We also thank Mr Knutsen for reviewing the English.

\section{LITERATURE CITED}

Andersen P, Sorensen HM (1986) Population dynamics and trophic coupling in pelagic microorganisms in eutrophic coastal waters. Mar Ecol Prog Ser 33:99-109

Azam F, Fenchel T, Field JG, Gray JS, Meyer-Reil LA, Thingstad F (1983) The ecological role of water-column microbes in the sea. Mar Ecol Prog Ser 10:257-263

Bardouil M, Bohec M, Bougrier S, Lassus P, Truquet P (1996) Feeding responses of Crassostrea gigas (Thunberg) to inclusion of different proportions of toxic dinoflagellates in their diet. Oceanol Acta 19:177-182

Barillé L, Prou J, Héral M, Bougrier S (1993) No influence of food quality, but ration-dependent retention efficiencies in the Japanese oyster Crassostrea gigas. J Exp Mar Biol Ecol 171:91-106

Bayne BL, Widdows J (1978) The physiological ecology of two populations of Mytilus edulis L. Oecologia 37:137-162

Berg JA, Newell RIE (1986) Temporal and spatial variations in the composition of seston available to the suspension feeder Crassostrea virginica. Estuar Coast Shelf Sci 23:375-386

Berk SG, Brownlee DC, Heinle DR, Kling HJ, Colwell RR (1977) Ciliates as a food source for marine planktonic copepods. Microb Ecol 4:27-40

Blanchard G, Sauriau PG, Cariou-Le Gall V, Gouleau D, Garet MJ, Olivier F (1997) Kinetics of tidal resuspension of microbiota: testing the effects of sediment cohesiveness and bioturbation using flume experiments. Mar Ecol Prog Ser 151:17-25

Bougrier S, Hawkins AJS, Héral M (1997) Preingestive selection of different microalgal mixtures in Crassostrea gigas and Mytilus edulis, analysed by flow cytometry. Aquaculture 150:123-134

Burkhardt S, Riebesell U (1997) $\mathrm{CO}_{2}$ availability affects elemental composition (C:N:P) of the marine diatom Skeletonema costatum. Mar Ecol Prog Ser 155:67-76

Caron DA (1983) Technique for enumeration of heterotrophic and phototrophic nanoplankton, using epifluorescence microscopy, and comparison with other procedures. Appl Environ Microbiol 46:491-498

Conover RJ (1982) Interrelations between microzooplankton and other plankton organisms. Ann Inst Océanogr, Paris $58: 31-46$

Coughlan J (1969) The estimation of filtering rate from the clearance of suspensions. Mar Biol 2:356-358

Deslous-Paoli JM, Héral M, Goulletquer P, Boromthanarat W, Razet D, Garnier J, Prou J, Barillé L (1987) Evolution saisonnière de la filtration de bivalves intertidaux dans des conditions naturelles. Oceanis 13:575-579

Fenchel T (1988) Marine plankton food chains. Annu Rev Ecol Syst 19:19-38

Fiala-Medioni A, Copello M, Colomines JC (1983) Relations trophiques entre huitre et milieu; influence de la concentration et de la taille des particules. Bases biologiques de l'aquaculture, IFREMER, Montpellier, Actes de colloques $n^{\circ} 1, p 53-74$

Frikha MG, Linley EAS, Delmas D (1987) Evolution annuelle et saisonnière de la microbiomasse d'une claire à huitres: importance des populations bactérioplanctoniques. Oceanis $13: 433-447$ 
Gerdes D (1983) The Pacific oyster Crassostrea gigas. Part I Feeding behaviour of larvae and adults. Aquaculture 31 $195-219$

Gifford DJ, Dagg MJ (1991) The microzooplankton-mesozooplankton link: consumption of planktonic protozoa by the calanoid copepods Acartia clausi Dana and Neocalanus plumchrus Murukawa. Mar Microb Food Webs 5:161-177

Glover HE, Campbell L, Prézelin BB (1986) Contribution of Synechococcus spp. to size-fractioned primary productivity in three water masses in the Northwest Atlantic Ocean. Mar Biol 91:193-203

Haas LW (1982) Improved epifluorescence microscopy for observing planktonic microorganisms. Ann Inst Océanogr 58:261-266

Hartmann HJ, Taleb H, Aleya L, Lair N (1993) Predation on ciliates by the suspension-feeding calanoid copepod Acanthodiaptomus denticornis. Can J Fish Aquat Sci, Paris 50:1382-1393

Heinbokel JF (1978) Studies on the functional role of tintinnids in the Southern California Bight. I. Grazing and growth rates in laboratory cultures. Mar Biol 47:177-189

Heral M (1987) Evaluation of the carrying capacity of molluskan shellfish ecosystems. In: IFREMER (ed) Shellfish culture development and management. International seminar, La Rochelle 4-9 March 1985. IFREMER, SDB, Brest

Johnson PW, Huai-Shu X, Sieburth J McN (1982) The utilization of chroococoid cyanobacteria by marine zooplankters but not by calanoid copepods. Ann Inst Océanogr, Paris 58:297-308

Jonsson PR, Tiselius P (1990) Feeding behaviour, prey detection and capture efficiency of the copepod Acartia tonsa feeding on planktonic ciliates. Mar Ecol Prog Ser 60:35-44

Jørgensen CB (1996) Bivalve filter feeding revisited. Mar Ecol Prog Ser 142:287-302

Kemp PF, Newell SY, Krambeck C (1990) Effects of filterfeeding by the ribbed mussel Geukensia demissa on the water-column microbiota of a Spartina alterniflora saltmarsh. Mar Ecol Prog Ser 59:119-131

Kreeger DA, Newell RIE (1996) Ingestion and assimilation of carbon from cellulolytic bacteria and heterotrophic flagellates by the mussels Geukensia demissa and Mytilus edulis (Bivalvia, Mollusca). Aquat Microb Ecol 11:205-214

Lam-Hoai $T_{1}$ Rougier $C_{1}$ Lasserre $G$ (1997) Tintinnids and rotifers in a northern Mediterranean coastal lagoon. Structural diversity and function through biomass estimations. Mar Ecol Prog Ser 152:13-25

Leakey RJG, Burkill PH, Sleigh MA (1992) Planktonic ciliates in Southampton Water: abundance, biomass, production, and role of pelagic carbon flow. Mar Biol 114:67-83

Leakey RJG, Burkill PH, Sleigh MA (1994) A comparison of fixatives for the estimation of abundance and biovolume of marine planktonic ciliate populations. J Plankton Res 16. $375-389$

Le Gall S, Bel Hassen M, Le Gall P (1997) Ingestion of a bacterivorous cliate by the oyster Crassostrea gigas: protozoa as a trophic link between picoplankton and benthic suspension-feeders. Mar Ecol Prog Ser 152:301-306

Legendre L, Le Fèvre J (1995) Microbial food webs and the export of biogenic carbon in oceans. Aquat Microb Ecol 9 : $69-77$

Li KW, Subba Rao DV, Harrison GW, Smith CJ, Cullen JJ, Irwin B, Platt T (1983) Autotrophic picoplankton in the tropical ocean. Science 219:292-295

Lovejoy C, Vincent WF, Frenette JJ, Dodson JJ (1993) Microbial gradients in a turbid estuary: application of a new method for protozoan community analysis. Limnol Oceanogr 38:1295-1303
Montagnes DJS, Lynn DH, Roff JC, Taylor WD (1988) The annual cycle of heterotrophic planktonic ciliates in the waters surrounding the Isles of Shoals, Gulf of Maine: an assessment of their trophic role. Mar Biol 99:21-30

Newell CR, Shumway SE, Cucci TL, Selvin R (1989) The effects of natural seston particle size and type on feeding rates, feeding selectivity and food resource availibility for the mussel Mytilus edulis Linnaeus, 1758 at bottom culture sites in Maine. J Shellfish Res 8:187-196

Ohman MD. Snyder RA (1991) Growth kinetics of the omnivorous oligotrich ciliate Strombidium sp. Limnol Oceanogr 36:922-935

Pastoureaud A, Héral M, Prou J Razet D, Russu P (1996) Particle selection in the oyster Crassostrea gigas (Thunbert) studied by pigment HPLC analysis under natural food conditions. Oceanol Acta 19:79-87

Paulmier G (1972) La nutrition des huitres en relation avec les sources trophiques. Rev Trav Inst Pêches Marit 36: $456-506$

Platt T, Subba-Rao DV, Irwin B (1983) Photosynthesis of picoplankton in the oligotrophic ocean. Nature 301:702-704

Pomeroy LR (1974) The ocean's food web, a changing paradigm. Bioscience 24:499-504

Pomeroy LR, Wiebe WJ (1993) Energy sources for microbial food webs. Mar Microb Food Webs 7:101-11.8

Porter KG, Pace ML, Battey JF (1979) Ciliate protozoans as links in freshwater planktonic food chains. Nature 277: $563-565$

Putt M. Stoecker DK (1989) An experimentally determined carbon:volume ratio for marine 'oligotrichous' ciliates from estuarine and coastal waters. Limnol Oceanogr 34: $1097-1103$

Rassoulzadegan F (1977) Evolution annuelle des ciliés pélagiques en Méditerrannée nord-occidentale. Ciliés oligotriches 'non tintinnides' (Oligotrichina). Ann Inst Océanogr, Paris 53:125-134

Rassoulzadegan F, Gostan J (1976) Répartition des ciliés pélagiques dans les eaux de Villefranche-sur-mer. Remarques sur la dispersion du microzooplancton en mer et à l'intérieur des échantillons dénombrés par la méthode d'Utermöhl. Ann Inst Océanogr, Paris 52:175-188

Revelante N, Gilmartin M (1983) Microzooplankton distribution in the northern Adriatic Sea with emphasis on the relative abundance of ciliated protozoans. Oceanol Acta 6 : 407-415

Riera P, Richard P (1996) Isotopic determination of food sources of Crassostrea gigas along a trophic gradient in the Estuarine Bay of Marennes-Oléron. Estuar Coast Shelf Sci $42: 347-360$

Riisgârd HU (1988) Efficiency of particle retention and filtration rate in 6 species of Northeast American bivalves. Mar Ecol Prog Ser 45:217-223

Robert JM (1983) Fertilité des eaux des claires ostréicoles et verdissement: utilisation de l'azote par les diatomées dominantes. Doctoral Thesis, University of Nantes, Nantes

Sherr EB, Sherr BF, Fallon. R, Newell SY (1986a) Small aloricate ciliate as a major component of the marine heterotrophic nanoplankton. Limnol Oceanogr 31 (1):177-183

Sherr EB, Sherr BF, Paffenhöfer GA (1986b) Phagotrophic protozoa as food for metazoans: a 'missing' trophic link in marine pelagic food webs? Mar Microb Food Webs 1: $61-80$

Sherr EB, Caron DA, Sherr BF (1994) Staining of heterotrophic protists for visualisation via epifluorescence microscopy. In: Kemp PF. Sherr BF, Sherr EB, Cole JJ (eds) Handbook of methods in aquatic microbial ecology. Lewis Publishers, Boca Raton, FL, p 213-227 
Shumway SE, Cucci TL, Newell RC, Yentsch CM (1985) Particle selection, ingestion, and absorption in filter-feeding bivalves. J Exp Mar Biol Ecol 91:77-92

Sime-Ngando T, Gosselin M, Roy S, Chanut JP (1995) Significance of planktonic ciliated protozoa in the Lower St. Lawrence Estuary: comparison with bacterial, phytoplankton, and particulate organic carbon. Aquat Microb Ecol 9:243-258

Soletchnik P, Prou J, Héral M, Barillé L, Razet D, Guezennec L (1991) Influence de la charge particulaire sur la filtration d'une population d'huitre Crassostrea gigas dans le bassin estuarien de Marennes-Oléron (France): analyse de deux cycles de marée. Int Counc Explor Sea Comm Meet (Shellfish Comm) F:53:1-10

Sournia A, Belin C, Berland B, Erard-Le Denn, Gentien P. Grzebyk D, Marcaillou-Le Baut C, Lassus P, Partensky F

Editorial responsibility: Otto Kinne (Editor),

Oldendorf/Luhe, Germany
(1991) Le phytoplancton nuisible des côtes de France. De la biologie à la prévention. IFREMER-CNRS, Brest

Stoecker DK, Capuzzo JMD (1990) Predation on protozoa: its importance to zooplankton. J Plankton Res 12:8981-908

Stoecker DK, Egloff DA (1987) Predation by Acartia tonsa Dana on planktonic ciliates and rotifers. J Exp Mar Biol Ecol 110:53-68

Strathmann RR (1967) Estimating the organic carbon content of phytoplankton from cell volume or plasma volume. Limnol Oceanogr 12:411-418

Vitiello P (1964) Contribution à l'étude des Tintinnides de la baie d'Alger. Pelagos, Bull Inst Océanogr Alger 2:5-18

Zanette $Y(1980)$ Intervention de quelques facteurs dans l'évolution de la biomasse des claires de MarennesOléron. Int Counc Explor Sea Comm Meet (Shellfish Comm) L:45:1-11

Submitted: March 16, 1998; Accepted: October 14, 1998 Proofs received from author(s): January 14, 1999 